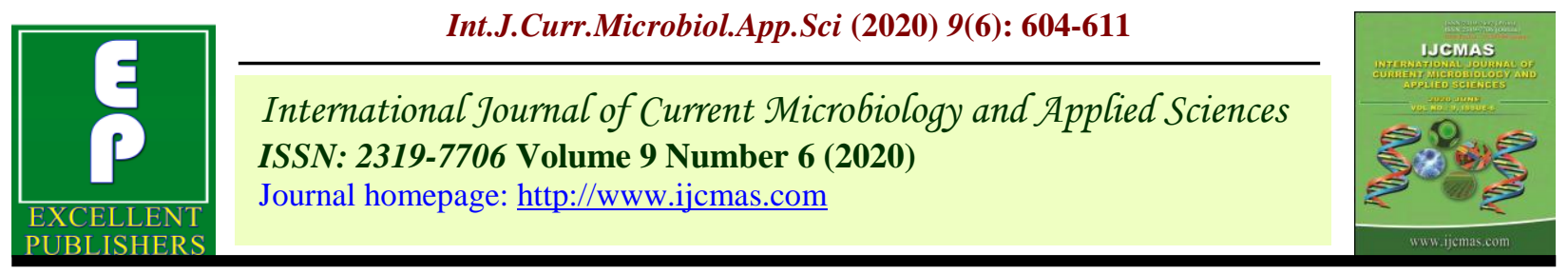

Original Research Article

https://doi.org/10.20546/ijcmas.2020.906.078

\title{
Impact of Skill Development Training Programmes on Scientific Backyard Poultry Farming in Bathinda District of Punjab (India)
}

\author{
Palwinder Singh*, G. S. Dhillon, A. P. S. Dhaliwal \\ Punjab Agricultural University, Ludhiana, India \\ Krishi Vigyan Kendra, Bathinda, India \\ *Corresponding author
}

\section{A B S T R A C T}

\section{Keywords \\ Impact, Backyard poultry, \\ Management, \\ Poultry, Skill \\ development etc}

Article Info

Accepted:

15 May 2020

Available Online:

10 June 2020
A study was conducted to assess the impact of skill development programmes on the level of adoption of backyard poultry farming practices in Bathinda district of Punjab. The information was collected from 469 respondents with the help of well-structured interview schedule cum questionnaire. The results of the study revealed that after getting the training, 207 farmers (44.14\%) adopted poultry farming as a subsidiary occupation. Before training, majority $(80.3 \%)$ of the rural poultry farmers were unaware about the improved management practices However after getting skill development training, 88.9 percent of farmers became aware about the health practices and a majority of them $(79.02 \%)$ adopted these management practices. The constraints identified were high death rate of birds $(91.8 \%)$, unavailability of quality poultry equipments $(83.1 \%)$, lack of veterinary aids $(79.7 \%)$ and high input cost $(71.5 \%)$. It indicates that government should design a module to provide soft loan, veterinary aids and quality poultry equipments to the backyard poultry farmers for their betterment. The training imparted to the farmers increased their knowledge and they got acquainted to new technologies of poultry farming.

\section{Introduction}

Livestock and Poultry provide a major contribution to the Indian Economy (Nath et al., 2012). Poultry production in India emerges as a poultry industry from backyard poultry production system. Nowadays, availability of poultry products in the rural areas is very low or unavailable due to their higher prices. Poultry farming is very old profession for providing cheap, readily harvest table protein rich eggs \& meat with high quality of nutrients for home consumption. Although, this bird was found in the Indian jungles before India's independence but it was identified by the Britishers during hunting in the jungles.

The recent research on this bird is done in the developed countries. During the early days small units of poultry farming was started in India. There is need to understand the perception of farmers on rearing of backyard poultry farming for the supplementation of 
family diet. The product under backyard poultry is very high in nutritious value and easily available for the sustainability of rural poor. Mandal et al., (2006) described nicely while giving a definition to the backyard poultry production system, According to them it is a low input or no input business and is characterized by indigenous night shelter system, scavenging system, with little supplementary feeding, natural hatching of chicks, poor productivity of birds, local marketing and no health care practice.

According to the Indian government's National Action Plan for Egg \& Poultry-2022 (NAPEP), backyard poultry accounts for 20 percent of India's poultry sector, which is worth over $\square 800$ billion. Across the country, around 30 million farmers are engaged in backyard poultry farming, estimates the 19th Livestock Census of India.

Though, rural backyard poultry has significant contribution in national egg production but it is still neglected in the consumption pattern. The few birds reared in rural areas have the sequencing habit with very low housing, feeding and management facilities which results in very low profit to the families. So there is a need to develop awareness regarding suitable breeds under backyard along with feeding, housing and disease control practices. This can put great impact on the rural farming families to develop backyard poultry system.

The native chicken varieties adopted in freerange backyard conditions for centuries contribute about 11 percent of total egg production in India (Kumaresan et al., 2008). Due to their low productivity (annual egg production@ 50-60 eggs/hen/year), their contribution to the total egg output was almost static for the last few decades. The role of backyard poultry farming in sustaining and enhancing poor peoples' livelihoods in developing countries is well recognized among the development community (Ahuja et $a l ., 2008)$. There is also growing evidence to demonstrate the role of backyard poultry in enhancing the food and nutrition security of the poorest households, reducing the livelihood vulnerability and insecurity, and promotion of gender equity (Ahuja and Sen, 2007). Backyard poultry is an important source of animal protein despite, the level of monthly income from backyard poultry farming being very low.

Realizing the potential offered by backyard poultry farming Krishi Vigyan Kendra, Bathinda initiated skill development training programmes on poultry farming especially focussed on backyard poultry production in rural areas of Bathinda district of Punjab. Backyard poultry production improves the socio economic status of rural farmers by adoption of this subsidiary occupation at village level. These need based skill development trainings have played a significant role in popularising backyard poultry among the rural youth, ex-service men, labourers, farmers and farm women. However, rare work has been carried out to study the impact of these skill development training programmes. Therefore, the present work has been designed to study the impact of these programmes organized by the Krishi Vigyan Kendras on the adoption of backyard poultry farming.

\section{Materials and Methods}

Krishi Vigyan Kendra Bathinda (Punjab) is one of the oldest Kendras of Punjab to provide training programmes on skill development in poultry farming. The sample of study was 469 trainees who acquired skill development training on scientific poultry farming during the period from 2016-17 to 2019-20. This information was collected by using a structural questionnaire from the 
trained farmers by visiting \& discussing with them personally, and the data was analysed for assessing the adoption of backyard poultry structure among farmers. To ascertain the adoption level of management practices by the farmers before and after the training, adoption scale was provided with the list of technologies adopted by the farmers to tick on, thereby indicating the level that was in the adoption scale and to identify constraints militating against adoption level. Data was analyzed with both descriptive and inferential statistics. The basic data of respondents is given in the Table 1.

\section{Results and Discussion}

In this study data presented in Table 2 shows the age, gender, education level, land holding, occupation, flock size, source of finance, and annual income from poultry units. Majority $(46.4 \%)$ of the poultry farmers had age group between 26-35 years which was followed by the age group 36-45 years (31.4\%), while 12.6 percent of respondents belonged to old age group of more than 45 years and 9.7 percent had age between 16-25 years. It is obvious from the data that greater part of the respondents, who were between age group of 26-35 years, had maximum adoption percentage of backyard poultry farming. The study indicated that larger part $(77.8 \%)$ of the respondents in Bathinda district were male, which indicated that adoption of poultry farming among rural women is very low. Among the respondents, 38.6 percent were primary educated followed by middle school $(37.7 \%)$, intermediate $(14.5 \%)$, graduate (5.8\%), and illiterate (3.4\%). Similar findings were reported by (Nath et al., 2012).

It is also revealed from Table 2 that majority $(77.8 \%)$ of the respondents belonged to farming community. 16.9 percent respondents were landless labourers followed by businessmen $(5.3 \%)$. It was concluded that majority of the backyard poultry farmers were engaged in farming. It shows that majority $(35.7 \%)$ of the respondents had less than 20 birds per flock, which was followed by the 21-40 birds per flock, 41-60 birds per flock (18.4\%) and more than 60 birds per flock (12.1\%). The small flock size may be attributed to lack of funds and marketing, or even high mortality rate due to low adoption of improved poultry management technologies by farmers before training. However, with the help of training this could be improved in future. Lawal et al., (2009) noted that poultry farmers expanded their flock size due to adoption of improved poultry techniques.

It is obtained from the study that the major source of finance was from their personal savings. Majority $(71 \%)$ of the respondents supported this view. Role of money lenders or villagers is only 20.3 percent followed by financial institution (8.7\%). About 37.7 percent of the respondents obtained an annual income of Rs 10,000-15,000 from backyard poultry, and 31.9 percent obtained Rs 15,00020,000. While, 30.4 percent of the respondents obtained income of Rs 20,00040,000 form their business per annum. If farmers increase production by adopting new technologies, they can increase their profit and income per year. The level of income realized from the venture even at small scale, may be the reason why farmers attended the training in order to learn new and more techniques in poultry production that may enhance productivity.

\section{Adoption of improved management practices by farmers before training}

The data presented in Table 3 revealed that 42 percent respondents were aware of culling, 28 percent of de-beaking, 27 percent respondents provided feed according to poultry age, 23 percent farmers were using antibiotics and 19 
percent farmers were rearing quality birds, however low adoption was recorded in postmortem of dead bird by veterinary doctors (7\%), brooding management $(13 \%)$, preparing feed formulation at household level (14\%), record keeping (14\%) and in use of feed supplementation (12\%). Use of disinfectants in farm and segregation of diseased birds obtained mean score of 18 percent. Thus, the data revealed that before training maximum respondents had medium to low adoption of poultry farming. It also showed that before training of improved management practices, poultry farmers were not much aware about the post-mortem of dead birds by veterinary staff, feed supplement uses, brooding management, record keeping and feed formulation at household level. Similar findings were also reported by Ezeibe et al., 2014.

\section{Adoption of improved management practices by farmers after training}

There is a significant adoption of all the improved poultry management practices after training (Table 3). A vast majority (99\%) of the respondents adopted timely treatment of sick bird and 98 percent farmers adopted culling, feed formulation at household level, and rearing of quality birds. 96 percent respondents consulted with veterinary doctors and provided feed according to age. The data also showed that similar adoption index was obtained for frequent visit to birds and debeaking (92\%), while for record keeping of birds was 89 percent. The view for above management practices were also supported by Ithika et al., 2013. Percentage gain in various improved backyard poultry rearing techniques is given in the figure 1. From, the figure it is clear that maximum gain was obtained in case of feed formulation (84\%) followed by rearing of quality birds $(79 \%)$ while minimum gain of 56 percent was obtained for culling and use of disinfectants.

\section{Constraints militating against poultry production among respondents}

From the study it was observed that majority of the backyard poultry farmers faced problems like high death rate of birds (Table 4). The highest mean score $(91.8 \%)$ was recorded for this parameter, while unavailability of quality poultry equipments showed mean score of 83.1 percent.

High death rate of birds and unavailability of quality poultry equipments were identified as major constraints and ranked at first and second position, respectively. Lack of veterinary aids obtained mean score of 79.7 percent and ranked third. High input cost of poultry unit exhibited mean score of 71.5 percent and achieved rank fourth. Difficulty in finance also perceived major constraints in poultry, and it gained mean score of $67.6 \%$. Lack of technical support ranked sixth, and obtained mean score of 57 percent. The similar findings are reported by Thorat (2005).

It is also evident from Table 4 that similar mean score of 55.6 percent was obtained for non-availability of improved breeds and dependency of market on brokers; while lack of initial capital showed mean score of 43.5 percent. Illiteracy among poultry farmers obtained a mean score of 34.8 percent which shows that if respondents were illiterate they would not gain the technology rapidly.

Poor quality of feed was also a major constraint which obtained 38.6 percent mean score, while 37.7 percent was obtained for high risk. Low egg production in summers was also a significant constraint for the development of poultry industry and the capacity of small producers in the particular field. Access to credit is of core importance to all the aspects of poultry industry as these may hide expansion (Olyemi et al., 2000). 
Table.1 Basic data and adoption percentage of respondents

\begin{tabular}{|l|c|c|c|}
\hline Year & Total no. trainees & $\begin{array}{c}\text { No. of trainees who adopted } \\
\text { poultry farming }\end{array}$ & $\begin{array}{c}\text { Adoption } \\
\text { percentage (\%) }\end{array}$ \\
\hline $\mathbf{2 0 1 6 - 1 7}$ & 99 & 38 & 38.38 \\
\hline $\mathbf{2 0 1 7 - 1 8}$ & 101 & 42 & 41.58 \\
\hline $\mathbf{2 0 1 8 - 1 9}$ & 94 & 43 & 45.74 \\
\hline $\mathbf{2 0 1 9 - 2 0}$ & 175 & 84 & 48.00 \\
\hline Total & $\mathbf{4 6 9}$ & $\mathbf{2 0 7}$ & $\mathbf{4 4 . 1 4}$ \\
\hline
\end{tabular}

Distribution of respondent based on socioeconomic characteristics of the backyard poultry farmers

\begin{tabular}{|c|c|c|}
\hline Characteristics & Frequency & Percentage \\
\hline \multicolumn{3}{|l|}{ Age (years) } \\
\hline $16-25$ & 20 & 9.7 \\
\hline 26-35 & 96 & 46.4 \\
\hline $36-45$ & 65 & 31.4 \\
\hline$>45$ & 26 & 12.6 \\
\hline \multicolumn{3}{|l|}{ Gender } \\
\hline Male & 161 & 77.8 \\
\hline Female & 46 & 22.2 \\
\hline \multicolumn{3}{|l|}{ Education level } \\
\hline Illiterate & 7 & 3.4 \\
\hline Primary & 80 & 38.6 \\
\hline Middle school & 78 & 37.7 \\
\hline Intermediate & 30 & 14.5 \\
\hline Graduate & 12 & 5.8 \\
\hline \multicolumn{3}{|l|}{ Land Holding } \\
\hline$<1$ acre & 71 & 34.3 \\
\hline 1-2 acre & 92 & 44.4 \\
\hline$>2$ acre & 44 & 21.3 \\
\hline \multicolumn{3}{|l|}{ Occupation } \\
\hline Farming & 161 & 77.8 \\
\hline Land less labours & 35 & 16.9 \\
\hline Businessmen & 11 & 5.3 \\
\hline \multicolumn{3}{|l|}{ Flock size } \\
\hline$<20$ bird & 74 & 35.7 \\
\hline $21-40$ & 70 & 33.8 \\
\hline $41-60$ & 38 & 18.4 \\
\hline$>60$ & 25 & 12.1 \\
\hline \multicolumn{3}{|l|}{ Source of finance } \\
\hline Personnel saving & 147 & 71.0 \\
\hline Money lender or village person & 42 & 20.3 \\
\hline Financial institution & 18 & 8.7 \\
\hline \multicolumn{3}{|l|}{ Annual Income (Rs.) } \\
\hline 10000-15000 & 78 & 37.7 \\
\hline $15000-20000$ & 66 & 31.9 \\
\hline 20000-40000 & 63 & 30.4 \\
\hline
\end{tabular}


Table.3 Adoption level of improved management practices before and after the training

\begin{tabular}{|c|c|c|c|c|}
\hline \multirow[t]{2}{*}{ Sr. no } & \multirow[t]{2}{*}{ Management Practices } & \multicolumn{2}{|c|}{ Adoption index (\%) } & \multirow[t]{2}{*}{ Gain (\%) } \\
\hline & & Before & After & \\
\hline 1 & Use of disinfectants in farm & 18 & 74 & 56 \\
\hline 2 & Record keeping & 14 & 89 & 75 \\
\hline 3 & Frequent visit to birds & 19 & 92 & 73 \\
\hline 4 & Brooding management & 13 & 74 & 61 \\
\hline 5 & Culling \& selection & 42 & 98 & 56 \\
\hline 6 & Use of antibiotics & 23 & 81 & 58 \\
\hline 7 & De-beaking & 28 & 92 & 64 \\
\hline 8 & Feed formulation at household level & 14 & 98 & 84 \\
\hline 9 & Timely treatment of sick bird & 21 & 99 & 78 \\
\hline 10 & $\begin{array}{l}\text { Post-mortem of dead bird by } \\
\text { veterinary doctors }\end{array}$ & 7 & 72 & 65 \\
\hline 11 & Segregation of diseased birds & 18 & 87 & 69 \\
\hline 12 & Feed supplement uses & 12 & 88 & 76 \\
\hline 13 & Provide feed according to age & 27 & 96 & 69 \\
\hline 14 & Rearing of quality birds & 19 & 98 & 79 \\
\hline \multirow[t]{2}{*}{15} & Consulting veterinary doctors & 21 & 96 & 75 \\
\hline & Mean value & 19.7 & 88.9 & 69.2 \\
\hline
\end{tabular}

Table.4 Distribution of respondents according to the problems faced

\begin{tabular}{|r|l|c|c|c|}
\hline S no. & \multicolumn{1}{|c|}{ Constraints } & Frequency & Mean Score & Rank \\
\hline $\mathbf{1}$ & Lack of veterinary aids & 165 & 79.7 & III \\
\hline $\mathbf{2}$ & $\begin{array}{l}\text { Unavailability of quality poultry } \\
\text { equipments }\end{array}$ & 172 & 83.1 & II \\
\hline $\mathbf{3}$ & Not available improved breeds & 115 & 55.6 & VII \\
\hline $\mathbf{4}$ & High death rate of bird & 190 & 91.8 & I \\
\hline $\mathbf{5}$ & Lack of technical support & 118 & 57.0 & VI \\
\hline $\mathbf{6}$ & Poor quality of feed & 80 & 38.6 & IX \\
\hline $\mathbf{7}$ & Dependency of market on Brokers & 115 & 55.6 & VII \\
\hline $\mathbf{8}$ & Lack of family support & 30 & 14.5 & XV \\
\hline $\mathbf{9}$ & Religious constraints & 25 & 12.1 & XVI \\
\hline $\mathbf{1 0}$ & Difficulty in finance & 140 & 67.6 & V \\
\hline $\mathbf{1 1}$ & Lack of initial capital & 72 & 43.5 & VIII \\
\hline $\mathbf{1 2}$ & Illiteracy among farmers & 148 & 71.8 & XII \\
\hline $\mathbf{1 3}$ & High input cost & 78 & 37.7 & IV \\
\hline $\mathbf{1 4}$ & High risk & 25 & 12.1 & XVI \\
\hline $\mathbf{1 5}$ & Difficulty in inputs availability & 40 & 19.3 & XIV \\
\hline $\mathbf{1 6}$ & Low egg price through whole sale & 75 & 36.2 & XI \\
\hline $\mathbf{1 7}$ & Lack of transportation & 70 & 33.8 & XIII \\
\hline $\mathbf{1 8}$ & Low egg production in summers & & & \\
\hline & & & & \\
\hline
\end{tabular}




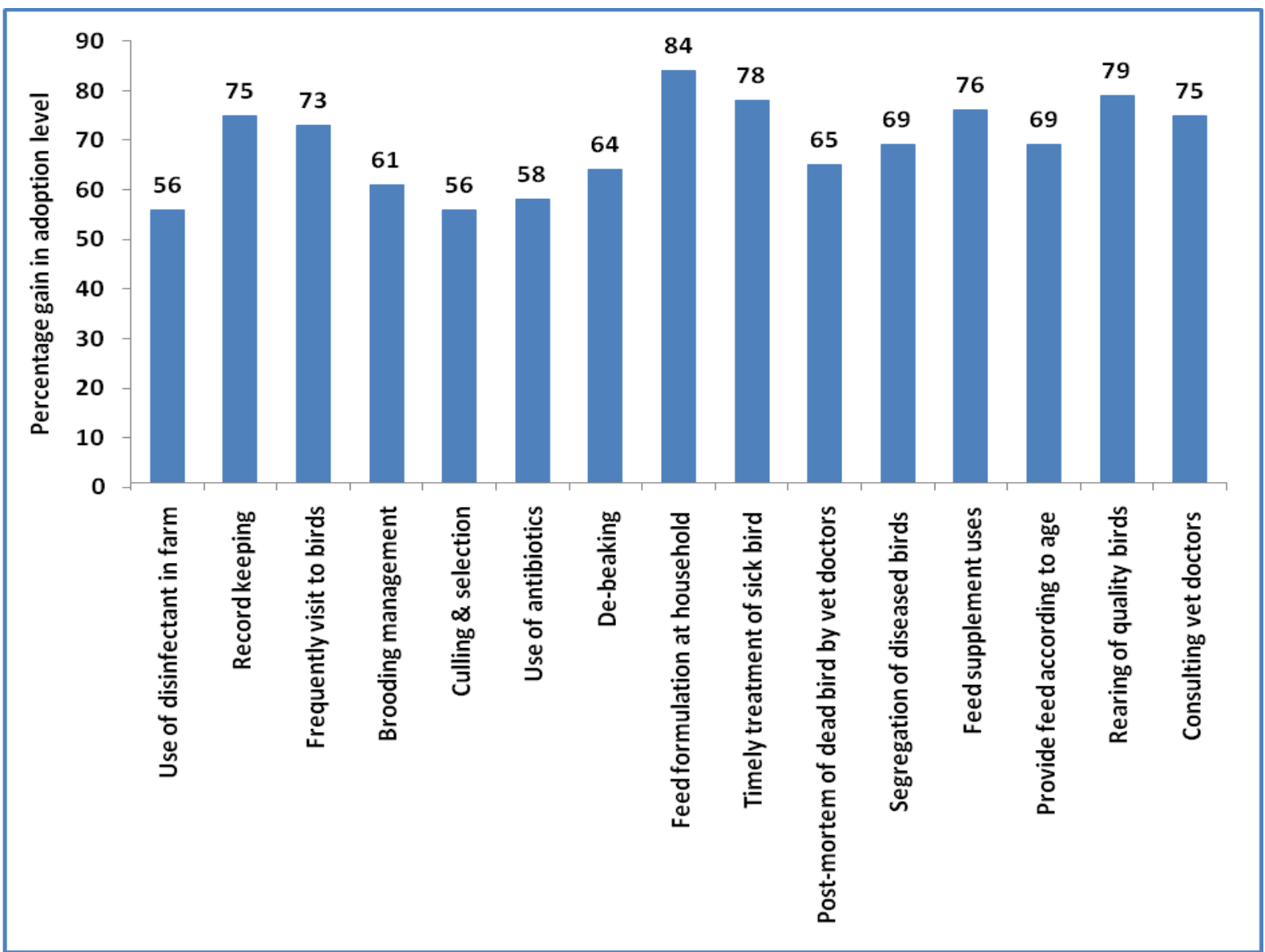

Fig.1 Percentage gain in the adoption level of technology

The study concluded that the training programmes have a tremendous impact on the adoption level of scientific methods of backyard poultry farming by rural farmers. Among different management practices timely treatment of sick birds had highest level of adoption percentage and least adoption percentage was observed for postmortem of dead birds by veterinary doctor.

Apart from this, major constraints in poultry farming were non-availability of quality birds, high death rate of birds, unavailability of quality poultry equipments, lack of veterinary aids and high input cost. It also revealed that rearing of quality birds and feed formulation technologies are emerging trends among the rural poultry units. This study also shows that the skill development training programmes are very useful for the rural youth as it brings more and more farmers under the umbrella of new skill training programmes to meet out daily expenditures from the subsidiary occupation.

\section{References}

Ahuja V, and Sen A. Viability and future of small scale commercial poultry production in developing countries. Paper presented at International Conference on Poultry in the 21st Century: Avian Influenza and Beyond, Bangkok, 2007; November 5-7.

Ahuja V, Dhawan M, Punjabi M and Maarse L. Poultry based livelihoods of rural poor: Case of Kuroiler in West Bengal. National Dairy Development Board of Indian and Food and Agriculture Organization of the United Nations, 
2008 p.57.

Bhattu BS, Dhaliwal APS, Singh S, \& Singh G. Impact of Vocational Trainings on Adoption of Dairy Enterprise in SouthWestern Districts of Punjab. Journal of Krishi Vigyan, 2015: 3(2), 62-65.

Ezeibe ABC, Okorji EC, Chah, JM and Abudei R.N. Impact of entrepreneurship training on poultry farmer's adoption of improved management practices in Enugustate, Nugeria. Academic Journals. 2014; 9:1604-1609.

Ithika, C.S., Singh, S.P. and Gautam, G. Adoption of scientific poultry farming practices by the broiler farmers in Haryana. India. Indian Journals of Applied Animal Science. 2013; 3: 417 422.

Kumaresan A, Bujarbaruah KM, Pathak KA Analysis of a village chicken production system and performance of improved dual purpose chickens under a subtropical hill agro-ecosystem in India. Trop Anim Health Prod 2008; 40, 395402.

Kushwah, Sunita, Kumar, Dharmendra. Impact evaluation of training programme on scientific backyard poultry rearing practices in Bihar (India). 2017;

10.13140/RG.2.2.24030.28485

Lawal BO, Toimiro DO, Makanjuoia BA. Impact of agricultural extension practices on the Nigereian poultry farmers standard of living: a perceptional analysis. Trop. Sub.Trop. Agro 2007; 10: 465-473.
Mandal AB, Tyagi PK, Shrivastav AK. Research priorities in poultry and nurtion and feed technology to 2020. In: Sasidhar, P.V.K (Ed.) Poultry Research priorities in 2020, Proceedings of National seminar, November 2-3, Central Avian Research Institute, Izatnagar. 2006; 96-114.

Mandal MK, Khandekar N, Khandekar P. Backyard poultry farming in Bareilly district of Uttar Pradesh, India: An analysis. Livestock Research for rural Development. 2006; 18 (7), http://www.irr.org.

Nath BG, Pathak PK, Mohanty AK. Scientific backyard poultry rearing technology: an approach to awareness and adoption of technology for livelihood development of rural farmers in Sikkim, India. Russian Journal of Agricultural and Socio-Economic Sciences. 2013; 22(10).

Nath BG, Toppo S, Chandra R, Chatlod LR and Mohanty AK. Level of adoption and constraints of scientific backyard poultry rearing practices in rural tribal areas of Sikkim, India. Journal of Animal and Feed Research. 2012; 2:133-138.

Ogunlade I, Adebayo SA. Socio-economic status of women and girls in Bangladesh. Journal of Nutrition. 2009; 133: 4027-4030.

Thorat GN. An analysis of poultry entrepreneurs knowledge about poultry management practices. M. Sc. (Agri.) thesis, G.A.U,2005; Sardarkushinagar.

\section{How to cite this article:}

Palwinder Singh, G. S. Dhillon and Dhaliwal. A. P. S. 2020. Impact of Skill Development Training Programmes on Scientific Backyard Poultry Farming in Bathinda District of Punjab (India). Int.J.Curr.Microbiol.App.Sci. 9(06): 604-611. doi: https://doi.org/10.20546/ijcmas.2020.906.078 